\title{
AC 2011-1465: SPECIAL SESSION: THE IMPACT OF THE GULF COAST OIL SPILL ON CHEMICAL ENGINEERING EDUCATION GULF COAST OIL SPILL CLEAN-UP TECHNOLOGIES USING ABSORBENT MATE- RIALS
}

\section{Willie (Skip) E. Rochefort, Oregon State University}

Skip Rochefort is currently an Associate Professor of Chemical Engineering and the Director of OSU Precollege Programs (http://oregonstate.edu/precollege) and the Center for Outreach in Science and Engineering for Youth (COSEY) at Oregon State University. He has degrees in Chemical Engineering from the University of Massachusetts (B.S., 1976), Northwestern University (M.S. 1978) and the University of California, San Diego (Ph.D., 1986). He has held several industrial research positions (Dow Chemical, Kodak, AT\&T Bell Labs), and since 1993 he has been on the faculty in the OSU Chemical Engineering Department. He is an OSU Honors College faculty and has been recognized for his teaching and advising activities by ASEE, AIChE, the College of Engineering, and Oregon State University. His research interest for the last 35 years has been in all areas of polymer engineering and science, and for the last 18 years in engineering education. His passion is K-12 outreach for the recruitment and retention of women and minorities into engineering, with the current focus on introducing engineering science at the middle school and high school levels. His K-12 outreach activities can be found at http://cbee.oregonstate.edu/education/.

\section{Gail Ellen Gerdemann, STEPs at Oregon State University}

Elementary classroom teacher for over 30 years including teaching junior high science as a Peace Corps volunteer in Montserrat, West Indies, 6th grade in Virginia, primary and intermediate grades in Albany and Corvallis, Oregon. K-5 STEPs Coordinator at Oregon State University funded by Howard Hughes Medical Institute grant since 1994 working with classroom teachers and university/community scientists developing STEM curriculum and training teachers. Currently employed by Corvallis School District to develop, pilot, manufacture materials kits, and inservice teachers for a complete K-5 engineering curriculum to meet Oregon's new standards. 
Special Session: The Impact of the Gulf Coast Oil Spill on Chemical Engineering Education

\section{Gulf Coast Oil Spill Clean-up Technologies Using Absorbent Materials}

Stephanie E. Silliman ${ }^{1}$, Audrey G. Oldenkamp ${ }^{2}$, Gail Gerdemann ${ }^{3}$ and Dr. Skip Rochefort ${ }^{2}$,

(1)Chemical Engineering Department, Carnegie-Mellon University, Pittsburgh, PA,

(2) School of Chemical, Biological and Environmental Engineering, Oregon State University, Corvallis,

(3) STEPs Program, Oregon State University, Corvalis, OR

\section{Introduction}

On April 20, 2010 the Deepwater Horizon drilling rig exploded, releasing approximately 210,000 gallons of oil per day into the Gulf of Mexico. On July 15, 2010 the gushing oil well was finally capped. Scientists estimate that a total of 205,800,000 gallons of crude oil leaked into the Gulf. The blowout is at a depth of one mile below the surface of the ocean. Most of the oil rises to the surface due to density differences, but some oil gets trapped in underwater currents and travels throughout the ocean. Surface oil cleanup using various absorbent technologies was the focus of an activity that was developed for both K-12 outreach and the First Year Chemical Engineering course at OSU. The absorbent materials chosen were: 1) Superabsorbant Polymer (SAP) sold specifically for the clean-up of oil spills; 2) Commercial cellulose-based absorbant material sold for the purpose of cleaning oil leaks; 3) Raw wool from the Willamette Valley (currently a waste product); and 4) A non-woven wool product currently sold as a disaster-relief blanket. Activities were developed for a wide range of skill levels to demonstrate the effectiveness of the different technologies, as well as the economics and efficacy of deployment of these technologies in the Gulf Coast region (e.g., could the current fishing fleet be deployed to use these technologies, and how could that be done).

\section{Material Presented in this Paper}

The format we have chosen to present the material is in the form of two laboratory experiments (or activities as they are called in K-12) for two distinct grade levels. One is an activity that has been used in the First Year Engineering Orientation course at Oregon State University (CBEE 101 in Fall 2010) and several times with high school students both at OSU and in their classrooms. The CBEE 101 activity was carried out with 170 first year students in lab sections of 30-33 with students. A complete data set for the CBEE 101 activity is included to demonstrate what type of data might be obtained in a class lab section (groups of three students). The second activity was adapted from the first to be more suitable for upper elementary and middle school students and has been beta tested in several classrooms. Typical classroom size was 30 students, with groups of 3-5 students depending on the existing classroom dynamics for group work. In both cases, all the information necessary to perform the experiments is provided, as well as a list of the materials used and where they might be obtained.

\section{Preliminary Results}

The authors have developed and tested these activities since the early summer of 2010 just after the Deepwater Horizon blow-out in the Gulf region, and right in the midst of the ongoing clean-up activities. The activity was received with great enthusiasm at all grade levels, as the students made a strong connection that they were learning something of extreme relevance and with very practical applications. There was no formal assessment carried out other than the student feedback.

Acknowledgements The authors are indebted to all the teachers and students that made developing and implementing these activities such a wonderful experience. 


\title{
First Year Engineering Orientation Course
}

\section{Gulf Oil Spill Clean-up: Oil Absorbing Materials}

\author{
Dr. Skip Rochefort, Stephanie Silliman, and Audrey Oldenkamp \\ School of Chemical, Biological, and Environmental Engineering \\ Oregon State University
}

\section{Background}

On April 20, 2010 the deepwater horizon oil drill column exploded. Since then, approximately 210,000 gallons of oil a day have been released into the Gulf of Mexico for a total of 205,800,000 gallons of oil. The blowout is at a depth of one mile below the surface of the ocean. Most of the oil rises to the surface of the ocean due to density differences, but some oil gets trapped in underwater currents and travels throughout the ocean. The surface cleanup is what we are looking into with this experiment.

\section{Vocabulary}

Absorption:

Adsorption:

Cuticle:

Hydrophobic:

Polymer:

Dispersant:

Absorbency (Adsorbancy) Ratio:

\section{Experiment Objective}

Our goal is to simulate a surface oil spill and test different oil absorbing materials for their effectiveness in oil removal and oil recovery. A variety of both natural and manmade materials will be tested and a conclusion as to which oil cleanup method would best serve the Deepwater Horizon blowout will be drawn.

\section{MATERIALS}

In order to complete this investigation you will need the following supplies for each group:

Marvel Mystery Oil (red) -approximately 25mL

Tap water with added salt (3.5wt $\% \mathrm{NaCl}$ to simulate sea water)

4 plastic petrie dishes (2 tops and 2 bottoms)

1 10mL syringe

1 plastic fork (to probe and remove materials)

Dish soap (any brand)

1 gram of Wool (raw sheep fleece)

1 gram of Wool (non-woven blanket)

0.5 grams of Oil Absorbing Polymer

1 gram of Recycled Cellulose Material

4 plastic sandwich size bags

1 pair of gloves per person

Paper towels to clean up spills

Extra Experiment: BOOM with wool (raw fleece) filling: nylon peds and 2-4 grams raw wool 


\section{OIL SPILL CLEANUP EXPERIMENT}

1. Examine the four oil cleanup materials. What do you notice about each one? What are their relative densities to one another? Are any of the materials similar? Record your observations.

2. Fill a petrie dish bottom (deeper half) halfway with salt water and add 3ml Marvel Mystery oil on top.

3. Weigh out approximately 1 gram (approx.) of wool (raw sheep fleece) and record the exact mass, place wool on top of oil in the salt water.

4. Note how the wool soaks up the oil. Slowly stir the wool with a fork. Allow 30-60 sec. for the wool to absorb the oil. Remove the wool, add more oil, replace the wool and continue this process until it appears to be "saturated". When the wool no longer absorbs the oil, the oil will begin to float on the surface of the water. This is a subjective determination, so have the group agree when the experiment is complete!

5. Record the volume of oil that was absorbed by your wool (raw fleece)

Calculate the Absorbancy Ratio (AR) $=\mathrm{ml} \mathrm{oil} / \mathrm{g}$ wool

Calculate percent oil recovered $=(\mathrm{mL}$ oil recovered $/ \mathrm{ml}$ oil absorbed $) * 100 \%$

6. Repeat steps 2-4 using oil with 1 gram (approx) non-woven wool blanket.

Calculate $A R=\mathrm{ml}$ oil $/ \mathrm{g}$ oil absorbing polymer.

Calculate percent oil recovered $=(\mathrm{mL}$ oil recovered $/ \mathrm{ml}$ oil absorbed $) * 100 \%$

7. Repeat steps 2-4 using oil with $0.5 \mathrm{~g}$ (approx.) oil absorbing polymer (use petrie dish top - shallow).

Calculate $A R=\mathrm{ml}$ oil $/ \mathrm{g}$ oil absorbing polymer.

Calculate percent oil recovered $=(\mathrm{mL}$ oil recovered $/ \mathrm{ml}$ oil absorbed $) * 100 \%$

8. Repeat steps 2-4 using oil with $2 \mathrm{~g}$ recycled cellulose material (use petrie dish top - shallow).

Calculate $\mathrm{AR}=\mathrm{ml}$ oil/g recycled cellulose material.

Calculate percent oil recovered $=(\mathrm{mL}$ oil recovered $/ \mathrm{ml}$ oil absorbed $) * 100 \%$

9. Fill a plastic cup halfway with salt water, add $5 \mathrm{ml}$ oil to the surface, then slowly add $5 \mathrm{~mL}$ of dish detergent and stir with a fork. Add more detergent as needed. This dish detergent simulates the dispersants being used in the Gulf. Record observations.

10. Record your DATA for all four absorbant materials on the data sheet provided.

This data will be later shared with the class for an analysis of the average absorbency ratio (AR) and experimental error (standard deviation).

\section{BOOM CREATION AND OIL RECOVERY EXPERIMENT}

1. Select the raw fleece wool material to use inside of your boom.

2. Weigh out 1-3 g of the raw wool and place it inside of a stocking. Secure with rubber bands or tie a knot and cut off extra stocking material.

3. Fill a plastic cup halfway with salt water and add $10 \mathrm{~mL}$ of oil using syringe.

4. Place boom on water surface, swirl it around if you wish. Record observations.

5. Using tweezers or tongs place boom in a plastic bag. Squeeze the boom inside of the plastic bag, letting oil drip to the bottom of the bag. Cut a small hole in the corner of the bag and drain oil into a graduated cylinder. Record measurement.

6. Calculate the Absorbancy Ratio (AR) $=\mathrm{ml} \mathrm{oil} / \mathrm{g}$ wool

7. Calculate percent oil recovered $=(\mathrm{mL}$ oil $\mathrm{recovered} / \mathrm{ml}$ oil absorbed $) * 100 \%$ 


\section{Data Table}

\begin{tabular}{|c|l|l|l|l|}
\hline Material & $\begin{array}{c}\text { Weight of } \\
\text { Material }\end{array}$ & $\begin{array}{c}\text { mL of Oil } \\
\text { Absorbed }\end{array}$ & $\begin{array}{c}\text { Absorbency } \\
\text { Ratio }\end{array}$ & Observations \\
\hline Polymer (SAP) & & & & \\
\hline Cellulose & & & & \\
\hline $\begin{array}{c}\text { Wool } \\
\text { (Raw Sheep } \\
\text { Fleece) }\end{array}$ & & & & \\
\hline $\begin{array}{c}\text { Wool } \\
\text { (woven } \\
\text { blanket) }\end{array}$ & & & & \\
\hline
\end{tabular}

\begin{tabular}{|c|l|l|l|l|}
\hline $\begin{array}{c}\text { Dispersant } \\
\text { (soap) }\end{array}$ & - & - & - & \\
& & & & \\
\hline
\end{tabular}

\section{Brainstorming}

How would your group engineer an oil spill clean-up method in the gulf? How would you get your material to the polluted waters? How would you remove the material? What would you do with the waste products? Use the pace below to address these issues. 


\section{Oil Spill Clean-Up Materials Information}

Cellulose (LITE-DRI ${ }^{\circledR}$ Oil-Only Loose Absorbent): http://www.newpig.com/

-Made of recycled cellulose - begins to absorb the moment it touches liquid

-Repels water while absorbing only oil-based liquids

-Ideal for use in machine shops, automotive shops, spill kits, fluid storage areas, loading docks

-Works well, but is much harder to recover from

Oil Absorbing Polymer: http://www.stevespanglerscience.com/product/1265

-A small amount of polymer bonds with the layer of oil forming a sponge-like material

-This can be easily removed from the surface of water

-Specially formulated to bond quickly and safely to many types of liquid hydrocarbons including crude oil, diesel fuel and gasoline (Hydrophobic)

\section{Wool:}

-Oregon wool is not typically used in textile production because of its short fiber length

-This means farmers have excess that cannot be sold for a profit

-Wool is a naturally oil absorbent material that can absorb approx. 8-10 times its weight in oil showing a clear option for the gulf clean-up

Needle Punched Wool Pad: http://www.northwestwoolen.com/Disaster.aspx

$-100 \%$ recycled wool blended fiber, made in the USA.

-Each pad is 36" x 36" and absorbs approx. 2.5 gallons of oil.

\section{Other oil clean up options:}

Wikipedia Information on the Deepwater Horizon Oil Spill:

http://en.wikipedia.org/wiki/Deepwater_Horizon_oil_spill

Use of bacteria to clean up oil:

http://www.redorbit.com/news/science/1878637/bacteria_strain_could_aid_in_oil_spill_cleanup/

Use of mushrooms to clean up oil:

http://pollution-control.suite101.com/article.cfm/can-mushrooms-help-clean-up-the-gulf-oil-spill 


\title{
Elementary and Middle School Activity
}

\section{Gulf Oil Spill Cleanup: Oil Absorbing Materials}

\author{
Gail Gerdemann, OSU STEPs Program
}

The Deepwater Horizon oil spill in April 2010 captured the world's attention and concern as scientists and engineers struggled to contain the oil and protect the Gulf Coast. An earlier generation watched in horror as the Exxon Valdez oil disaster unfolded and people rushed to rescue Alaskan wildlife. These two events can seem overwhelming and hopeless to young people, but knowledge can give a sense of hope. This curriculum unit is targeted for upper elementary and middle school students.

In the process of doing engineering design, students will be introduced to important elements of engineering: criteria for success, constraints, budgets, and trade-offs. They also have an opportunity to propose and test possible solutions to a practical problem, to improve their design, and to share their findings with others. This engineering project is designed to match the National Research Council's National Science Standards for 5-8 Abilities of Technological Design: ${ }^{\text {i }}$ identify appropriate problems for technological design, design a solution or product, implement a proposed design, evaluate completed technological designs or products, and communicate the process of technological design.

The lab described earlier in this paper and developed for undergraduates can be adapted for success for students in grades four to eight. The age-appropriate adaptations for younger students include: (1) presenting the context for the problem, (2) choosing appropriate materials, (3) devising a materials distribution and cleanup system, and (4) helping students understand trade-offs by using scoring guides to measure success and constraints.

Presenting the context for an engineering problem needs to be interesting, build on students' current knowledge, and appropriate for the age of the students. For this oil spill cleanup project, there are three possible approaches that work well with students in the middle years. One way to launch the challenge is to read a story featuring a child with a similar problem to solve; the story can give scientific background information, real-life context, and introduce the engineering design process. The Boston Museum of Science's Engineering is Elementary program has just such a story, Tehya's Pollution Solution in their unit A Slick Solution: Cleaning an Oil Spill." Another good way to introduce the problem and give information about what others have done is to read non-fiction juvenile literature that includes photographs and diagrams about the technology. Oil Spill! ${ }^{i i i}$ describing the Alaskan event is meant for primary children, but the diagrams and photographs provide good information to launch a discussion. Many new books have been written for children about the Gulf Oil Spill: Oil Spill! Disaster in the Gulf of Mexico, ${ }^{i v}$ Gulf Coast Oil Spill: Poor Little Pelican + KidReport Photo Documentary, ${ }^{v}$ and Oil Spill. ${ }^{v i}$ Any of these books could be used to introduce the topic. One other way to successfully begin an engineering project is to have students research the topic online. Three good resources to use with students this age are: National Wildlife's Federation's Ranger Rick's The Big Oil Spill, ${ }^{\text {vii }}$ National Marine Educator's Association / NOAA's Bridge Oil Spill, ${ }^{\text {viii }}$ and PBS's Newshour Extra Capping and Cleaning Up the Oil Spill. ${ }^{\text {ix }}$ An excellent resource for educators is the U.S. Environmental Protection Agency's Teaching Resources. ${ }^{x}$

Using safe, inexpensive, and easily found materials guarantees that a lesson can be done in classrooms everywhere. For the oil in these lessons, add an oil-based food dye (can be found in stores that sell cake and candy decorating supplies) to vegetable oil so that the oil is easily visible as it floats on the mini-ocean, a Petri dish or 
pie pan of water. Common household items can be used as booms: rubber bands or pieces of yarn or string taped in a circle the same size as the rubber band. To simulate clean-up equipment, use plastic spoons as scoops or eyedroppers for suction or other ideas students might have after learning about commercial large-scale techniques. The possibilities for absorbents are all around: coffee filters, cotton balls, small pieces of sponges, paper towels, felt, cut up washcloths, etc. For dispersants, use liquid dish detergent or

Young adults can successfully gather and clean up their own materials, but the wise teacher of younger students plans methods that insure that this happens. For this lab, all the materials can be set out on a table as the Materials Store. After writing up a design proposal, a budget, and rationale for why the design is expected to be successful, each team is ready to gather materials. One student from each group is assigned to pick up the materials the group needs. In the typical classroom with thirty students and one sink, a water distribution and disposal system needs to be planned. For this lab use Petri dishes (or other small wide pans) to reduce the amount of water needed for each test; each group has a small container of water at their station and another empty container for disposing of waste water to reduce trips to the sink. Also have a large tub for the class for collecting waste water to be disposed outside later. It works well to have the teacher be the oil spill distributor, walking around the room and dispensing equal amounts of oil on each group's "ocean." Determine what your standard amount of oil will be; three droppers full will produce a spill about one inch in diameter.

Key aspects of engineering design are the concepts of criteria for success, constraints, and the trade-offs between them. Students are familiar with scoring guides for their work in math, science, and writing and these are a good way to bring the idea of trade-offs into focus in an engineering design project. In cleaning up an oil spill, there are two major criteria for success: removing the oil to protect the environment and if possible, recovering the valuable oil for further use. Additionally in the real world, the amount of money available is finite and the less spent the better and so a budget is essential. Students score their designs on these three parameters and add together for a final score -- in this case the lowest score is best.

For the clean-up score, they note how much oil still remains on the water that could potentially harm the environment. Scores range from zero for all the oil is removed to five for no oil is removed. A guide with different sized circles can help determine how much oil is still floating on the water: one-inch circle for five points, half-inch circle for 3 points, and one-fourth circle for 1 point. The best score is zero for no oil remaining on the ocean and the worst is five for all the oil still floating on the ocean.

For the oil recovery score, students note how much oil they have transferred to the lid of the Petri dish (which should also contain water to float the oil for easier scoring). Using the same sized circle guide, the points are in inverse relationship to the points. If all the oil ends up in the recovery container (one-inch circle), the points are five, but the score is zero; if no oil ends up in the recovery container, the points are zero and the score is five. By comparing these two scores, students can deduce how much oil was lost in the process, perhaps absorbed but not recoverable. Finally students are scored on the amount of materials they use for their design. Assign dollar amounts for each material, using millions makes this fun, and a related score from one to five with one representing minimal use of materials and five representing the maximum allowed use of materials. It is important with younger students to have a budget cap to reduce excessive materials usage and keep your real costs down. 
An opportunity to reflect on the first design and do a redesign is important in the engineering design process. Student teams should reflect on their original design and decide what they would like to do differently; teams write up their second design proposal with their plan, budget, and rationale and qualify for a second round at the Materials Store. After two design opportunities, have teams write up their conclusions and prepare a presentation for the class. Review the problem solved, solutions suggesting, testing results, and recommended design that best reflect a balance of success in cleaning up and recovering the oil with the least expense.

\footnotetext{
i National Research Council, National Science Standards, National Academy Press, 1996

ii Engineering is Elementary, Museum of Science, Boston, Massachusetts, A Slick Solution: Cleaning an Oil Spill, 2010

iii Berger, Melvin, Oil Spill!, Harper Collins, 1994

iv Landau, Elaine, Oil Spill! Disaster in the Gulf of Mexico, Millbrook Press, 2011

" Marsh, Carole, Gulf Coast Oil Spill: Poor Little Pelican + KidReport Photo Documentary, Gallopade International, 2010

${ }^{2 i}$ Caputo, Christine, Oil Spill, Capstone, 2010

vii National Wildlife Federation web resource: http://www.nwf.org/Kids/Ranger-Rick/People-and-Places/RangerRick-on-the-Big-Oil-Spill.aspx

viii NOAA website: http://www2.vims.edu/bridge/search/bridge1output_menu.cfm?q=spill

${ }^{i x}$ PBS Newshour website: http://www.pbs.org/newshour/extra/teachers/lessonplans/science/julydec10/oilspill_07-27.html

${ }^{x}$ U.S. Environmental Protection Agency, Teacher Resources, http://www.epa.gov/teachers/ecosystems.htm
} 


\begin{tabular}{|c|c|c|c|c|c|c|c|c|c|c|c|c|c|c|c|c|c|c|c|c|}
\hline \multicolumn{21}{|c|}{ CBEE 101 Fall 2010 Section 1} \\
\hline Group & $\begin{array}{l}\text { Polymer } \\
\text { SAP }\end{array}$ & $\begin{array}{l}\text { mass Material } \\
\text { grams }\end{array}$ & $\begin{array}{c}\text { oil absorbed } \\
\mathrm{ml}\end{array}$ & $\begin{array}{c}\text { AR } \\
\mathrm{ml} \mathrm{oil/g}\end{array}$ & $\begin{array}{c}\text { \%rec } \\
\text { ml }\end{array}$ & Cellulose & $\begin{array}{l}\text { mass Material } \\
\text { grams }\end{array}$ & $\begin{array}{c}\text { oil absorbed } \\
\mathrm{ml}\end{array}$ & $\begin{array}{c}\text { AR } \\
\mathrm{ml} \mathrm{oil/g}\end{array}$ & $\%$ rec & $\begin{array}{l}\text { Wool } \\
\text { fleece }\end{array}$ & $\begin{array}{l}\text { mass Material } \\
\text { grams }\end{array}$ & $\begin{array}{c}\text { oil absorbed } \\
\mathrm{ml}\end{array}$ & $\begin{array}{c}\text { AR } \\
\mathrm{ml} \mathrm{oil/g}\end{array}$ & \%rec & $\begin{array}{c}\text { Wool } \\
\text { blanket }\end{array}$ & $\begin{array}{l}\text { mass Material } \\
\text { grams }\end{array}$ & $\begin{array}{c}\text { oil absorbed } \\
\mathrm{ml}\end{array}$ & $\begin{array}{c}\text { AR } \\
\mathrm{ml} \mathrm{oil/g}\end{array}$ & $\%$ rec \\
\hline 1 & & 0.496 & 4 & 8.06 & 0 & & 1.011 & 3 & 2.97 & 0 & & 1.017 & 10 & 9.83 & 100 & & 0.353 & 5 & 14.16 & 60 \\
\hline 2 & & 0.515 & 5 & 9.71 & 0 & & 1.075 & 4 & 3.72 & 12.5 & & 1.196 & 9 & 7.53 & 33.3 & & 0.388 & 6 & 15.46 & 33.3 \\
\hline 3 & & 0.548 & 5 & 9.12 & 0 & & 1.04 & 4 & 3.85 & 22.5 & & 1.036 & 12 & 11.6 & 98.3 & & 0.369 & 5 & 13.55 & 38 \\
\hline 4 & & 0.563 & 3.7 & 6.57 & 0 & & 1.389 & 4 & 2.88 & 20 & & 1.168 & 9 & 7.7 & 67.8 & & 0.421 & 6 & 14.25 & 11 \\
\hline 5 & & 0.516 & 10 & 20 & 0 & & 2.002 & 6 & 3 & 8 & & 1.005 & 16 & 16 & 63 & & 0.413 & 8 & 20 & 44 \\
\hline 6 & & 0.514 & 3.5 & 6.81 & 0 & & 1.036 & 4 & 3.86 & 32.5 & & 0.946 & 7 & 7.34 & 70 & & 0.396 & 5 & 12.63 & 50 \\
\hline 7 & & 0.502 & 6 & 12 & 0 & & 1.026 & 6 & 5.8 & 0 & & 0.998 & 27 & 27.1 & 65 & & 0.377 & 5 & 13.3 & 28 \\
\hline 8 & & 0.5 & 5.5 & 11 & 0 & & 1 & 4 & 4 & 12.5 & & 1.16 & 20 & 24.1 & 95 & & 0.388 & 7 & 18.04 & 42.9 \\
\hline 9 & & 0.45 & 5 & 11.1 & 0 & & 2.162 & 5 & 2.132 & 10 & & 1.093 & 11 & 10.064 & 86 & & 0.473 & 4 & 8.457 & 25 \\
\hline 10 & & 0.519 & 7 & 13.5 & 0 & & 0.988 & 3 & 3.04 & 3.3 & & 1.075 & 11 & 10.2 & 72.7 & & 0.514 & 6 & 11.7 & 35 \\
\hline 11 & & 0.5 & 20 & 40 & 0 & & 1 & 4 & 4 & 12.5 & & 1 & 11 & 14 & 64 & & 0.357 & 5 & 14 & 40 \\
\hline Average & & & & 13.4 & & & & & 3.6 & 12.2 & & & & 13.2 & 74.1 & & & & 14.1 & 37.0 \\
\hline Std Deviation & & & & 9.6 & & & & & 1.0 & 9.9 & & & & 6.7 & 19.7 & & & & 3.0 & 13.1 \\
\hline
\end{tabular}

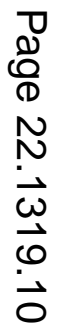

